\title{
Does Firms Have Impact of Currency Appreciation and Currency Volatility on Market Shares?-Study of Selected Financial and Non-Financial Firms of India
}

\author{
Rashmi Soni \\ K J Somaiya Institute of Management Studies and Research, Mumbai, India \\ Email: rashmi.soni@somaiya.edu
}

How to cite this paper: Soni, R. (2018) Does Firms Have Impact of Currency Appreciation and Currency Volatility on Market Shares?_-Study of Selected Financial and Non-Financial Firms of India. Theoretical Economics Letters, 8, 1004-1017. https://doi.org/10.4236/tel.2018.85069

Received: February 14, 2018

Accepted: April 10, 2018

Published: April 13, 2018

Copyright $\odot 2018$ by author and Scientific Research Publishing Inc. This work is licensed under the Creative Commons Attribution International License (CC BY 4.0).

http://creativecommons.org/licenses/by/4.0/ (c) (i) Open Access

\begin{abstract}
This study concentrates on the new emerging challenges, opportunities and issues in the field of Exchange Rate Risk. It highlights the strong and significant negative impact from currency appreciation and currency volatility on market shares of India's Exporting Financial and Non-Financial IT firms. Quantitative data analysis of companies has been done and evaluating the Sales/Revenue growth performance of Indian firms on various measures/factors like operating profit, gross profit, net profit etc. Further, we identify the dependent and independent variables and predict the factors that highly influence the fluctuations in Exchange rate. Finally, we suggest a model at the end and offer Suggestions and Recommendations to mitigate this risk arising due to currency fluctuations and increase the investor's awareness about financial derivatives leading to important policy implications so as to make forex gains on account of hedging using forward contract rather than just aiming to square off its position.
\end{abstract}

\section{Keywords}

Exchange Rate, Export, Performance, Risk, Currency

\section{Introduction}

Foreign exchange risk also known as FX risk, exchange rate risk or currency risk, is a financial risk that exists when a financial transaction is denominated in a currency other than that of the base currency of the company. Foreign exchange risk also exists when the foreign subsidiary of a firm maintains financial statements in a currency other than the reporting currency of the consolidated entity. 
The risk is that there may be an adverse movement in the exchange rate of the denomination currency in relation to the base currency before the date when the transaction is completed. Investors and businesses exporting or importing goods and services or making foreign investments have an exchange rate risk which can have severe financial consequences; but steps can be taken to manage (i.e., reduce) the risk.

\section{Exchange Rate and Firm-Level Exports}

The overall trade activity of a country is a sum of the decisions of individual firms. Hence, understanding the effects of exchange-rate changes on trade balance calls for an analysis of how exchange-rate fluctuations affect the decisions of individual firms. Such analysis provides insights into the varied responses across firms to exchange-rate movements and related policy implications of central bank's efforts to manage and stabilize foreign-exchange fluctuations.

Compared with other firms, exporting firms are usually associated with higher levels of productivity and profitability. Moreover, a strong export sector might generate positive effects for other sectors that promote overall economic growth. India has witnessed strong economic performance coupled with a strong export sector in the past decade. Thus, it is quite conceivable that export-promoting policies are conducive to economic growth. Against this background, we explore how fluctuations in the exchange rate affects decisions of Indian exporting firms, and whether the data suggests a weakening of the link between REER and exports.

Using a rich firm-level dataset, I will examine the varied responses of firms to exchange-rate fluctuations in a large developing economy. Some of the questions that will be dealt with will include:

- What is the impact of exchange-rate depreciation (appreciation) on exports of Indian manufacturing firms?

- Does the textbook prediction that exchange-rate depreciation (appreciation) boosts (deters) exports hold for Indian firms or is there no significant association?

- What are the firm-specific features that influence their export responses to exchange-rate changes?

- What is the macro features of the economy as a whole that impact firm-level export responses to exchange-rate movements?

\section{Review of Literature}

Charlie, Adith \& Singh, S Ronendra 2013 [1], this study examines the forex gains or losses on the profit and loss side are a function of multiple things- what is the exchange rate at the end (of the quarter), how the contracts are hedged, what particular derivative instruments are used and at what price. Any forex losses that may have will be on account of forward contracts maturing during the quarter, although that should get offset by translation gains, which is reported as 
part of other income. Indian IT firms refrain from focusing on making that extra buck through currency movements Yin-Wong Cheung and Rajeswari Sengupta 2013, [2] the study studies the objective and comes up with the end result that strong and significant negative impact from currency appreciation and currency volatility on market shares of India's exporting firms. Indian firms with smaller export shares tend to respond more strongly to both REER change and volatility than those with larger export shares. Services exporters are impacted more strongly by exchange rate fluctuations than firms exporting goods. Raghavendra, R H; Velmurugan, P S 2014, [3] the study in the light of globalization and internationalization of world markets, foreign exchange risk cannot be avoided but needs to be managed by hedging instruments. The need and approach for managing it depends on the size of exposure and fluctuations in exchange rate. Indian IT sector is known for development of software and it mainly depends on exports. They are required to measure and manage exchange rate risk. The study is an attempt to document the currency hedging practice by IT firms of India. Pasmantier, Anita B 1993, [4] the study studies the objective and comes up with the end result that corporate treasury managers face the dilemma every day of what to do with their firms' foreign exchange exposure. Once a decision to hedge has been made, the question then arises of which hedging tool to use. Among the available choices are: forward contracts, futures contracts, money market hedges, and option contracts. Because of the simplicity of entering into a forward contract, it is the hedging tool used most commonly by corporate foreign exchange managers. A currency option provides the right but not the obligation to carry through with the stipulated option contract. Kanas, Angelos 1996, [5] this study examines a model of exchange rate economic exposure faced by an exporting firm which participates in a competitive globalized export market is developed. This firm is assumed to have a market share expansion objective and publish a dual-currency price list. The issue of hedging is also discussed on the basis of currency derivative instruments. It is shown that the risk profile of economic exposure is asymmetric depending whether the domestic currency depreciates or appreciates. A. Kanagaraj1 and Ekta Sikarwar 2011, [6] the study examines the level of foreign exchange exposure and its determinants for a sample of Indian firms. For this purpose, the relationship between exchange rate changes and stock returns for a sample of 361 Indian non-financial firms is determined over April 2006-March 2011. The study finds that only 16 percent of the firms are exposed to exchange rate exposure at 10 percent level of significance. Furthermore, out of the firms having significant exposure, 86 percent firms are negatively affected by an appreciation of the rupee which confirms that Indian firms are net exporters. Miriti, M. 2004, [7] this study explores the proposition for informal or quasi-formal institutions to deliver forms of insurance to the poor. Innovation of risk management instruments is motivated as an anti-poverty policy. Particular attention is on exposures from mass covariant events, e.g. weather or other natural disasters. The study does not however investigate the 
survivability of the microfinance institution. It is limited to the investigation of household-risk implications, of local aggregation of covariant risk upon an index-insured pool in which the household is a member. Lingxiu Donga, Panos Kouvelisa, Ping Sub 2014, [8] the paper investigates the impact of operational flexibility on firms' economic exposure to currency fluctuations in the presence of global competition. Comparing the effects of two operational strategies of the global firm, namely, matching currency footprints ("natural hedge") and the capacity pooling strategy with allocation flexibility. For a two-stage stochastic model, they derive the optimal capacity and selling decisions for the global firm, and from the comparative statics analysis of the model they infer useful managerial insights. Akshatha B. G. 2013, [9] the study studies the objective and comes up with the end result that the reason that financial derivatives exist is due to risk. Investors use financial derivatives to reduce risk when they make a trade. Derivatives are excellent tool for risk management through hedging. Hedge is a way of protecting limiting or controlling something. Hedging in relation to the activity of investing devotes protection against risk arising out of unanticipated change in future price of instruments. The paper concentrates on the new emerging challenges, opportunities and issues in the field of financial derivatives. Dhargalkar, Amol 2015, [10] the study studies the objective and comes up with the end result that the common challenges involved in hedging foreign exchange risk as in early 2015 ushered in currency volatility and dollar strength unseen in decades. Rozsa Attila 2014, [11] the study studies the objective and comes up with various methods for decreasing exchange risks of foreign currency transactions. In international trade due to the growth of the number of currency loans the significance of managing financial risks coming from the changes in exchange rates has increased. One of its tools is the currency-based booking, which may make the effect of the change more predictable.

Existing literature has large number of study on derivative, exchange rate risk of it firms and some of the study for Non-IT firms as well. Research has found a gap in literature that there is no any specific study on currency appreciation and currency volatility on market share for Indian firms. This study will see the effect of currency appreciation and currency volatility on market share of financial and non-financial firms in India for the period of ten years.

\section{Research Methodology}

\subsection{Data Description \& Time Zone of the Data}

The sample of firms for the study has been primarily sourced from S \& P CNX 500 index which covers broad range of firms disaggregated into various industries. The S \& P CNX 500 is India's first broad-based stock market index of the Indian stock market. The S \& P CNX 500 represents about $96 \%$ of total market capitalization and about $93 \%$ of the total turnover on the National Stock Exchange of India (NSE). It represents the top 500 companies based on full market capitalisation from the eligible universe. 
Since the primary focus of the study was on both financial as well as non-financial firms, 3 firms each were initially identified from prowess database under these categories. Omission of some firms because of the non-availability of valuation data during the period of study i.e. from March 2006 to March 2015 reduced the final sample size to 6 . The decision to examine the financial and non-financial firms was based on the attempt to reduce the complexity of foreign exchange rate exposure and understand the risk management techniques used by these firms.

The USD-INR currency rates have been obtained from the internet and financial data from the ACE ANALYSER database, Company annual reports and various sites like Moneycontrol.com, Yahoofinance.com etc.

The data used includes past 10 years monthly USD-INR currency rates and year on year quantitative factors are studied for the period from $1^{\text {st }}$ March 2006 to $1^{\text {th }}$ March 2015.

Time zone used is Indian Standard Time and the Quantitative factors are of Indian IT companies and Indian Banks.

\subsection{Sampling Technique}

The sample period of research used for analysis was considered from March 2006 to March 2015 because: -

RBI has changed the base year of its exchange rate indices from 1993-94 to 2004-05 in November 2005. So, choosing this period would eliminate the differences of the changes that RBI made to its prior 36 countries and 5 countries nominal exchange rate index.

The following financial (banks) and non-financial companies (IT companies) are chosen as the sample for the research: -

Indian Financial Firms (Banks)

- State Bank of India (SBI).

- ICICI Bank.

- Axis Bank. Indian Non-Financial Firms (IT companies)

- Tata Consultancy Services (TCS).

- Wipro.

- Infosys.

The above mentioned companies are chosen as the sample for the research because: -

- These are companies which are rated excellent in all their respective domains.

- Volumes are high and foreign exchange trades are carried on a large scale.

- These are best fit for a novice person to understand the impact of exchange rate risk on Indian firms considering that information about them is extensively available.

Sample of previous 10-year annual quantitative factors of a company has been used and further correlation and regression techniques have been used to find 
the impact of exchange rate risk on these factors. The process has been used for all of the 6 companies taken as sample.

Independent variables i.e. 10 years monthly USD-INR currency rates data has been obtained by ACE ANALYSER Database and all the data is then tabulated to find out the correlation.

\subsection{Research Design}

Hypothesis: The following Quantitative factors are best indicators for predicting the impact of foreign exchange rate risk on Non-financial Indian firms (IT companies):

- Net Sales.

- Operating Profit.

- Tax Obligations.

- Equity Dividend.

- Earnings per share.

The following Quantitative factors are best indicators for predicting the impact of foreign exchange rate risk on Financial Indian firms (Banks):

- Interest Spread.

- Non-Performing Assets (NPA's).

- Net Profit.

- Earnings per share.

The objective is mainly to help a person to understand the impact of fluctuation of foreign exchange USD-INR rate on various parameters. Hence the hypothesis has been chosen accordingly.

\subsection{Data Sources for Each Variable}

USD-INR exchange rate-Obtained from Reuters website.

Various quantitative factors of the companies for the last 10 years, obtained from Ace Analyzer Database, Company annual reports and various sites like Moneycontrol.com, Yahoofinance.com etc.

\subsection{Testing and Data Analysis Techniques}

For the sake of consistency, we obtained all companies quantitative factors at the fiscal year-end, which is March for our sample of firms.

We do not have any explanatory variable based on reported earnings per share.

- We began by segregating the Indian firms into financial firms (Banks) and Non-financial firms (IT companies).

- For each of the above categories, 3 companies each are chosen and the annual profit and loss statement is obtained over a period of $1^{\text {st }}$ March'06 to $1^{\text {th }}$ March'15.

- Similarly, a dataset of past 10 years monthly USD-INR currency rates is obtained over a period of $1^{\text {st }}$ Jan'06 to $31^{\text {st }}$ Dec' 15 .

- The data of average USD-INR currency rates is then collated with the quan- 
titative data collected for all the firms corresponding to their names.

- Correlation Technique is then applied to find the relation between the fluctuations of the USD-INR currency rates and each of the quantitative factors of every firm.

- The idea behind correlation technique is to understand the similarity between different quantitative factors and USD-INR currency fluctuations.

- We then move forward and perform the regression process to find a dependency of different quantitative factors on the USD-INR currency fluctuations

\subsection{Data Analysis}

The sample of average USD-INR currency rates collated against the 5 selected quantitative factors is analyzed and data regression is carried out using the Inferential Statistics. Inferential Statistics is useful here because we want to determine the correlation and regression between various quantitative factors namely Net Sales, Operating Profit, Tax Obligations, Equity Dividend, Earnings per share for Non-financial Indian firms (IT companies) and Interest Spread, Non-Performing Assets (NPA's), Net Profit, Earnings per share for Financial Indian firms (Banks) against Average weekly market Returns.

Two types of correlation: Pearson and Spearman have been used to find the relation between variables. Each category shows different results in terms of Correlations and Regression which is shown in below tables. Table 1 shows the year on year average USD-INR exchange rate growth. Table 2 shows the year on year change in USD-INR exchange rate and quantitative factors of TCS.

Considering the data from Table 2 and applying the regression, ANOVA and correlation with the help of SPSS software we find that the least R Square value is approx. 62\% for Operating Profit while the maximum is approx. $85 \%$ with Earnings per share (Table 3 ). Hence, there is only $62 \%$ dependence of Operating Profit of TCS on fluctuating currency rate. Similarly, there is $85 \%$ dependence of earnings per share of TCS on fluctuating currency rate.

Table 1. The year on year Average USD-INR exchange rate and Exchange Rate Growth.

\begin{tabular}{ccc}
\hline Year & Average USD/INR & Exchange Rate Growth \\
\hline 2015 & 64.15348 & 3.13 \\
2014 & 61.02838 & 2.43 \\
2013 & 58.59618 & 5.17 \\
2012 & 53.42478 & 6.75 \\
2011 & 46.67194 & 0.95 \\
2010 & 45.71846 & -2.65 \\
2009 & 48.37193 & 4.90 \\
2008 & 43.46851 & 2.25 \\
2007 & 41.21569 & -4.04 \\
2006 & 45.25533 & \\
\hline
\end{tabular}


Table 2. The year on year change in USD-INR exchange rate and quantitative factors of TCS.

\begin{tabular}{ccccccc}
\hline Years & $\begin{array}{c}\text { Exchange rate } \\
\text { Growth }\end{array}$ & Net Sales & $\begin{array}{c}\text { Operating } \\
\text { Profit }\end{array}$ & $\begin{array}{c}\text { Tax } \\
\text { Obligation }\end{array}$ & $\begin{array}{c}\text { Equity } \\
\text { Dividend }\end{array}$ & $\begin{array}{c}\text { Earnings Per } \\
\text { Share (Rs) }\end{array}$ \\
\hline $2015-2014$ & 3.13 & 8905.13 & -505.52 & 223.46 & 9206.54 & 4.14 \\
$2014-2013$ & 2.43 & 16246.79 & 7227.45 & 2152.71 & 1961.45 & 28.94 \\
$2013-2012$ & 5.17 & 9567.60 & 2920.55 & 526.49 & -587.16 & 9.26 \\
$2012-2011$ & 6.75 & 9583.13 & 2622.19 & 1259.91 & 2152.94 & 17.35 \\
$2011-2010$ & 0.95 & 6230.96 & 2096.36 & 392.55 & -1174.33 & 10 \\
$2010-2009$ & -2.65 & 642.53 & 646.34 & 397.52 & 2544.38 & -19.3 \\
$2009-2008$ & 4.90 & 3868.20 & 995.22 & -117.21 & 0.00 & 1.85 \\
$2008-2007$ & 2.25 & 3593.75 & 724.13 & 46.78 & 244.66 & 7.68 \\
$2007-2006$ & -4.04 & 3709.47 & 964.07 & 91.35 & 464.83 & -17.14 \\
\hline
\end{tabular}

Table 3. Regression and Correlation analysis between Exchange rate risk and quantitative factors of TCS.

\begin{tabular}{cccc}
\hline Factors & R Square & ANOVA P value & Correlation \\
\hline Exchange rate risk and Net Sales & 0.750794354 & 0.029684017 & 0.797324278 \\
Exchange rate risk and Operating Profit & 0.620031655 & 0.055657368 & 0.627216121 \\
Exchange rate risk and Tax obligations & 0.656590006 & 0.0505716743 & 0.724012303 \\
Exchange rate risk and Equity Dividend & 0.756879096 & 0.0536588976 & 0.784933886 \\
Exchange rate risk and Earnings per share & 0.852217448 & 0.027861796 & 0.822616411 \\
\hline
\end{tabular}

The $\mathrm{P}$ value which is an indicator of the effectiveness of the regression shows that Operating profit is least affected with the change in exchange rate with around 5.5\% $\mathrm{P}$ value and earnings per share being the most effected with $2 \% \mathrm{P}$ value.

The correlation is found to be least with Operating Profit with just 63\% value, and maximum with earnings per share with $82 \%$ value, which shows that the 2 variables are highly correlated to each other (Table 3 ).

Considering the data from Table 4 and applying the regression, ANOVA and correlation with the help of SPSS software we find that the least $\mathrm{R}$ Square value is only $67 \%$ for operating profit while the maximum is approx. $91 \%$ with Net Sales (Table 5). Hence, there is only $67 \%$ dependence of operating profit of Wipro on fluctuating currency rate. Similarly, there is only $91 \%$ dependence of net sales of Wipro on fluctuating currency rate.

The $\mathrm{P}$ value which is an indicator of the effectiveness of the regression shows that Operating profit is least effected with the change in exchange rate with around $8 \% \mathrm{P}$ value and net sales being the most effected with $3 \% \mathrm{P}$ value.

The correlation for almost all the factors except for Operating profit shows a correlation more than $70 \%$, with net sales being the highest with approx. $86 \%$ which means that one variable increases with an increase in the other (Table 5). 
Table 4. The year on year change in USD-INR exchange rate and Quantitative factors of Wipro.

\begin{tabular}{ccccccc}
\hline Years & $\begin{array}{c}\text { Exchange } \\
\text { rate Growth }\end{array}$ & Net Sales & Operating Profit & $\begin{array}{c}\text { Tax } \\
\text { Obligations }\end{array}$ & $\begin{array}{c}\text { Equity } \\
\text { Dividend }\end{array}$ & $\begin{array}{c}\text { Earnings Per } \\
\text { Share (Rs) }\end{array}$ \\
\hline $2015-2014$ & 3.13 & 2452.60 & 90.90 & 143.10 & 990.00 & 3.23 \\
$2014-2013$ & 2.43 & 5530.70 & 2174.90 & 665.90 & 248.90 & 7.01 \\
$2013-2012$ & 5.17 & 1543.60 & 890.50 & 321.40 & 249.50 & 3.89 \\
$2012-2011$ & 6.75 & 5382.40 & 282.10 & 371.70 & 2.60 & -0.68 \\
$2011-2010$ & 0.95 & 3378.50 & 259.40 & 71.00 & 591.70 & -13.63 \\
$2010-2009$ & -2.65 & 1414.70 & 742.80 & 216.70 & 294.90 & 13.06 \\
$2009-2008$ & 4.90 & 4014.70 & 1043.10 & 167.70 & -290.50 & -0.66 \\
$2008-2007$ & 2.25 & 3808.70 & 461.10 & 72.30 & 2.80 & 1.48 \\
$2007-2006$ & -4.04 & 3456.78 & 770.61 & 48.00 & 160.82 & 5.31 \\
\hline
\end{tabular}

Table 5. Regression and Correlation analysis between Exchange rate risk and quantitative factors of Wipro.

\begin{tabular}{cccc}
\hline \multicolumn{1}{c}{ Factors } & R Square & ANOVA P value & Correlation \\
\hline Exchange rate risk and Net Sales & 0.913972065 & 0.037426796 & 0.86429749 \\
Exchange rate risk and Operating Profit & 0.67189743 & 0.081996579 & 0.613739103 \\
Exchange rate risk and Tax obligations & 0.710961796 & 0.03841308 & 0.731086026 \\
Exchange rate risk and Equity Dividend & 0.733790861 & 0.0418727517 & 0.683519246 \\
Exchange rate risk and Earnings per share & 0.810219742 & 0.040169082 & 0.783196833 \\
\hline
\end{tabular}

Considering the data from Table 6 and applying the regression, ANOVA and correlation with the help of SPSS software we find that the least R Square value is approx. 63\% for Operating Profit while the maximum is approx. $82 \%$ with Earnings per share (Table 7). Hence, there is only $63 \%$ dependence of Operating Profit of Infosys on fluctuating currency rate. Similarly, there is $82 \%$ dependence of earnings per share of Infosys on fluctuating currency rate.

The $\mathrm{P}$ value which is an indicator of the effectiveness of the regression shows that Operating profit is least affected with the change in exchange rate with around $6.5 \% \mathrm{P}$ value and earnings per share being the most effected with $2 \% \mathrm{P}$ value.

The correlation is found to be least with Operating Profit with just 62\% value, and maximum with earnings per share with $82 \%$ value, which shows that the 2 variables are highly correlated to each other (Table 7).

Considering the data from Table 8 and applying the regression, ANOVA and correlation with the help of SPSS software we find that the least $\mathrm{R}$ Square value is only $42 \%$ for earnings per share while the maximum is approx. $98 \%$ with Interest spread (Table 9). Hence, there is only $42 \%$ dependence of earnings per share of SBI on fluctuating currency rate. While, there is high dependence of Interest spread of SBI on fluctuating currency rate. 
Table 6. The year on year change in USD-INR exchange rate and Quantitative factors of Infosys.

\begin{tabular}{ccccccc}
\hline Years & $\begin{array}{c}\text { Exchange } \\
\text { rate Growth }\end{array}$ & Net Sales & $\begin{array}{c}\text { Operating } \\
\text { Profit }\end{array}$ & $\begin{array}{c}\text { Tax } \\
\text { Obligations }\end{array}$ & $\begin{array}{c}\text { Equity } \\
\text { Dividend }\end{array}$ & $\begin{array}{c}\text { Earning Per } \\
\text { Share (Rs) }\end{array}$ \\
\hline $2015-2014$ & 3.13 & 8905.13 & -505.52 & 826.00 & 1493.00 & 4.14 \\
$2014-2013$ & 2.43 & 16246.79 & 7227.45 & 567.00 & 1206.00 & 28.94 \\
$2013-2012$ & 5.17 & 9567.60 & 2920.55 & 131.00 & -287.00 & 9.26 \\
$2012-2011$ & 6.75 & 9583.13 & 2622.19 & 732.00 & -746.00 & 17.35 \\
$2011-2010$ & 0.95 & $6,230.96$ & 2096.36 & 661.00 & 2011.00 & 10 \\
$2010-2009$ & -2.65 & 642.53 & 646.34 & 822.00 & 89.00 & -19.3 \\
$2009-2008$ & 4.90 & 3868.20 & 995.22 & 265.00 & -557.00 & 1.85 \\
$2008-2007$ & 2.25 & 3593.75 & 724.13 & 278.00 & 1253.00 & 7.68 \\
$2007-2006$ & -4.04 & 3709.47 & 964.07 & 49.00 & -589.00 & -17.14 \\
\hline
\end{tabular}

Table 7. Regression and Correlation analysis between Exchange rate risk and quantitative factors of Infosys.

\begin{tabular}{cccc}
\hline Factors & R Square & ANOVA P value & Correlation \\
\hline Exchange rate risk and Net Sales & 0.750794354 & 0.036968402 & 0.766937243 \\
Exchange rate risk and Operating Profit & 0.630073585 & 0.065657368 & 0.627216121 \\
Exchange rate risk and Tax obligations & 0.656590006 & 0.050571674 & 0.684012303 \\
Exchange rate risk and Equity Dividend & 0.687909639 & 0.053658898 & 0.738493389 \\
Exchange rate risk and Earnings per share & 0.822174478 & 0.027861796 & 0.822616411 \\
\hline
\end{tabular}

Table 8. The year on year change in USD-INR exchange rate and Quantitative of SBI.

\begin{tabular}{cccccc}
\hline Years & $\begin{array}{c}\text { Exchange } \\
\text { rate Growth }\end{array}$ & $\begin{array}{c}\text { Interest } \\
\text { Spread }\end{array}$ & Gross NPA & $\begin{array}{c}\text { Net Profit } \\
\text { for the Year }\end{array}$ & $\begin{array}{c}\text { Share (Rs) } \\
\text { Shing Per }\end{array}$ \\
\hline $2015-2014$ & 3.13 & 5733.08 & -4880.01 & 2210.40 & -128.33 \\
$2014-2013$ & 2.43 & 4950.87 & 10415.96 & -3213.81 & -60.32 \\
$2013-2012$ & 5.17 & 1040.22 & 11512.93 & 2397.69 & 31.74 \\
$2012-2011$ & 6.75 & $10,764.68$ & 14350.17 & 4336.94 & 58.39 \\
$2011-2010$ & 0.95 & 8854.96 & 5791.40 & -1795.70 & -28.30 \\
$2010-2009$ & -2.65 & 2798.30 & 3946.29 & 44.82 & 0.70 \\
$2009-2008$ & 4.90 & 3851.91 & 2751.26 & 2392.11 & 37.11 \\
$2008-2007$ & 2.25 & 967.02 & 12837.34 & 2187.81 & 20.27 \\
$2007-2006$ & -4.04 & 418.57 & 0.00 & 134.64 & 2.56 \\
\hline
\end{tabular}

The $\mathrm{P}$ value which is an indicator of the effectiveness of the regression shows that Earnings per share is least effected with the change in exchange rate with around $5.9 \% \mathrm{P}$ value and Interest spread being the most effected with almost $1 \%$ $P$ value.

The correlation is found to be least with earnings per share with just $57 \%$ 
Table 9. Regression and Correlation analysis between Exchange rate risk and quantitative factors of SBI.

\begin{tabular}{cccc}
\hline Factors & R Square & ANOVA P value & Correlation \\
\hline Exchange rate risk and Interest Spread & 0.972667793 & 0.0131044 & 0.944414725 \\
Exchange rate risk and Gross NPA & 0.811549372 & 0.02128709 & 0.859944966 \\
Exchange rate risk and Net profit & 0.695044251 & 0.06306981 & 0.643179759 \\
Exchange rate risk and Earnings per share & 0.421893188 & 0.05959952 & 0.570540039
\end{tabular}

value, and maximum with Interest spread with $95 \%$ value, which shows that the 2 variables are highly correlated to each other (Table 9).

Considering the data from Table 10 and applying the regression, ANOVA and correlation with the help of SPSS software we find that the least R Square value is almost $54 \%$ for earnings per share while the maximum is approx. $80 \%$ with Interest spread (Table 11). Hence, there is no dependence of earnings per share of Axis bank on fluctuating currency rate. While, there is very high dependence of Interest spread of Axis bank on fluctuating currency rate.

The $\mathrm{P}$ value which is an indicator of the effectiveness of the regression shows that Earnings per share is least effected with the change in exchange rate with very high $\mathrm{P}$ value and Interest spread being the most effected with almost $0 \% \mathrm{P}$ value.

The correlation is found to be $56 \%$ with earnings per share, and maximum with Interest spread with approx. $90 \%$ value, which shows that the 2 variables are highly correlated to each other (Table 11).

Considering the data from Table 12 and applying the regression, ANOVA and correlation with the help of SPSS software we find that the least R Square value is only $62 \%$ for earnings per share while the maximum is approx. $82 \%$ with Interest spread (Table 13). Hence, there is only $62 \%$ dependence of earnings per share of SBI on fluctuating currency rate. While, there is high dependence of Interest spread of SBI on fluctuating currency rate.

The $\mathrm{P}$ value which is an indicator of the effectiveness of the regression shows that Earnings per share is least effected with the change in exchange rate with around $8.9 \% \mathrm{P}$ value and Interest spread being the most effected with almost 3\% $P$ value.

The correlation is found to be least with earnings per share with just $52 \%$ value, and maximum with Interest spread with $87 \%$ value, which shows that the 2 variables are highly correlated to each other (Table 13).

\section{Conclusions}

For the Non-Financial Indian Firms IT Companies, it is observed that the Correlation is found to be maximum with Earnings per share and net sales, in the case of Wipro, while almost all firms show the least correlation with Operating profit. This stands in accordance with the research done previously. The least $\mathrm{R}$ 
Table 10. The year on year change in USD-INR exchange rate and Quantitative factors of Axis Bank.

\begin{tabular}{cccccc}
\hline Years & $\begin{array}{c}\text { Exchange rate } \\
\text { Growth }\end{array}$ & $\begin{array}{c}\text { Interest } \\
\text { Spread }\end{array}$ & Gross NPA & $\begin{array}{c}\text { Net Profit for Earning Per } \\
\text { the Year }\end{array}$ & $\begin{array}{c}\text { Share (Rs) } \\
2015-2014\end{array}$ \\
3.13 & 2272.50 & 963.78 & 1140.15 & -101.29 \\
$2014-2013$ & 2.43 & 2285.38 & 752.99 & 1038.24 & 21.65 \\
$2013-2012$ & 5.17 & 1648.51 & 587.12 & 937.22 & 8.01 \\
$2012-2011$ & 6.75 & 1454.76 & 210.36 & 853.72 & 20.13 \\
$2011-2010$ & 0.95 & 1558.50 & -58.36 & 873.96 & 20.48 \\
$2010-2009$ & -2.65 & 1318.27 & 97.90 & 699.17 & 11.49 \\
$2009-2008$ & 4.90 & 1100.86 & 102.90 & 744.33 & 20.63 \\
$2008-2007$ & 2.25 & 1018.28 & 21.20 & 412.00 & 6.54 \\
$2007-2006$ & -4.04 & 488.85 & 64.43 & 173.95 & 5.99 \\
\hline
\end{tabular}

Table 11. Regression and Correlation analysis between Exchange rate risk and quantitative factors of Axis Bank.

\begin{tabular}{cccc}
\hline Factors & R Square & ANOVA P value & Correlation \\
\hline Exchange rate risk and Interest Spread & 0.785282749 & 0.001463772 & 0.886161808 \\
Exchange rate risk and Gross NPA & 0.792049813 & 0.015418367 & 0.831895314 \\
Exchange rate risk and Net profit & 0.646858024 & 0.075193445 & 0.628894654 \\
Exchange rate risk and Earnings per share & 0.540951716 & 0.083720293 & 0.560849896 \\
\hline
\end{tabular}

Table 12. The year on year change in USD-INR exchange rate and Quantitative factors of ICICI.

\begin{tabular}{cccccc}
\hline Years & $\begin{array}{c}\text { Exchange rate } \\
\text { Growth }\end{array}$ & $\begin{array}{c}\text { Interest } \\
\text { Spread }\end{array}$ & Gross NPA & $\begin{array}{c}\text { Net Profit for } \\
\text { the Year }\end{array}$ & $\begin{array}{c}\text { Earning Per } \\
\text { Share (Rs) }\end{array}$ \\
\hline $2015-2014$ & 3.13 & 4912.99 & 4588.85 & 1364.87 & -65.67 \\
$2014-2013$ & 2.43 & 4102.55 & 898.09 & 1485.01 & 12.78 \\
$2013-2012$ & 5.17 & 6532.95 & 132.42 & 1860.21 & 16.08 \\
$2012-2011$ & 6.75 & 7568.60 & -558.93 & 1313.88 & 11.36 \\
$2011-2010$ & 0.95 & 267.12 & 158.26 & 1126.40 & 8.63 \\
$2010-2009$ & -2.65 & -5385.62 & -445.50 & 266.85 & 2.34 \\
$2009-2008$ & 4.90 & 304.21 & 328.30 & -399.60 & -3.61 \\
$2008-2007$ & 2.25 & 7794.05 & 0.90 & 1047.51 & 2.78 \\
$2007-2006$ & -4.04 & 9209.79 & 9.85 & 570.15 & 6.04 \\
\hline
\end{tabular}

square value is of operating profit while the maximum value is that with Earnings per share and Net sales (In case of Wipro). Hence, there is least dependence of operating profit of these firms on fluctuating currency rate. Similarly, there is high dependence of Earnings per share of these firms on fluctuating currency rate. 
Table 13. Regression and Correlation analysis between Exchange rate risk and quantitative factors of ICICI Bank.

\begin{tabular}{cccc}
\hline Factors & R Square & ANOVA P value & Correlation \\
\hline Exchange rate risk and Interest Spread & 0.815853605 & 0.033053317 & 0.864194225 \\
Exchange rate risk and Gross NPA & 0.840288042 & 0.060457949 & 0.790071881 \\
Exchange rate risk and Net profit & 0.63340447 & 0.047553605 & 0.58367558 \\
Exchange rate risk and Earnings per share & 0.621139793 & 0.081826746 & 0.520174361
\end{tabular}

The $\mathrm{P}$ value which is an indicator of the effectiveness of the regression shows that operating profit is least affected with the change in exchange rate and earnings per share and net sales (for Wipro) being the most affected.

For the Financial Indian Firm i.e. Banks, it can be said that the correlation is found to be maximum with interest spread, while almost all firms show the least correlation with earnings per share. The least $\mathrm{R}$ square value is of earnings per share while the maximum value is that with interest spread. Hence, there is least dependence of earnings per share of these firms on fluctuating currency rate. The $\mathrm{P}$ value which is an indicator of the effectiveness of the regression shows that earnings per share are least affected with the change in exchange rate and interest spread being the most affected.

In studying the financial and non-financial firm's quantitative factors that have explanatory effect of year on year change in USD-INR exchange rate, one should consider all the variables that have been found to be significant by researcher. Although there is no consensus on which single factor best explains effect of year on year change in USD-INR exchange rate. Several studies find that earnings per share of each of these firms comes out to be a major factor while differentiating the effect of USD-INR currency rate on IT and Non-IT firms. It has been found that earnings per share show maximum correlation with exchange rate risk for non-financial firms and minimum correlation for financial firms. Moreover, the $\mathrm{R}$ square value of earnings per share is maximum for IT firms and least for banks. This further proves, there is least dependence of earning per share of non-IT firms means banks on fluctuating currency rate. While there is high dependence of earnings per share of IT firms on fluctuating currency rate. Also, the $\mathrm{P}$ value which is an indicator of the effectiveness of the regression shows that the earnings per share is the most affected for IT firms while least affected for banks.

For IT firms, fluctuating exchange rate risk shows least correlation with operating profit while for bank, fluctuating exchange rate risk shows maximum correlation with interest spread. These characteristics could be considered to understand the effect of year on year change in USD-INR exchange rate on Indian firms. However, there is no guarantee that a quantitative factor that has been proven significant for specific firms and during specific time periods could be an efficient indicator in different firms or time period. 


\section{Limitations \& Future Research Scope}

This research has some limitations like researcher has studied only three major firms each from financial as well as non-financial firms. This study is based on the last ten years fluctuations in the USD-INR rate. Thus, one should not expect these research result to work perfectly in the real world; rather they should use these findings as guide for their own hedging strategies. For future research, researcher can take some other factor to study the impact other than EPS and net profit like ROA and advances in case of other firms. This kind of study could be done in other industry which are involved in export in not only Indian perspective but global as well.

\section{References}

[1] Charlie, A. and Singh, S.R. (2013) Rupee Effect: Hedging Losses May Play Spoilsport for It Companies in Q2. Business Line.

[2] Cheung, Y. and Sengupta, R. (2013) Impact of Exchange Rate Movements on Exports: An Analysis of Indian Non-Financial Sector Firms. Bofit Discussion Papers, 10, 1-30.

[3] Raghavendra, R.H. and Velmurugan, P.S. (2014) A Survey of Currency Hedging Practices by Indian It Firms. Journal of Commerce and Management Thought, 5, 574-593. https://doi.org/10.5958/0976-478X.2014.00005.6

[4] Pasmantier, A.B. (1993) Hedging Foreign Exchange Exposure. Journal of Cash Management, 13, 36.

[5] Kanas, A. (1996) Exchange Rate Economic Exposure When Market Share Matters and Hedging Using Currency Options. Management International Review, 36, 67.

[6] Kanagaraj, A. and Sikarwar, E. (2011) A Firm Level Analysis of the Exchange Rate Exposure of Indian Firms. Journal of Applied Finance and Banking, 1, 163-184.

[7] Miriti, M. (2004) Hedging Smallholder Common Risk with Instruments for Microfinance (Order No. 3123815). Abi/Inform Complete (305174109).

[8] Dong, L., et al. (2014) Operational Hedging Strategies and Competitive Exposure to Exchange Rates. International Journal of Production Economics. https://doi.org/10.1016/j.ijpe.2014.03.002

[9] Akshatha, B.G. (2013) Financial Derivatives: An Innovative Financial Instrument to Hedge Risk. International Journal of Applied Financial Management Perspectives, 2, 294-299.

[10] Dhargalkar, A. (2015) Common Challenges to Hedging Foreign Exchange Risk. Corporate Finance Review, 20, 14-23.

[11] Attila, R. (2014) Opportunities for Decreasing Exchange Risks of Foreign Currency Transactions in Enterprises with a Special Regard on Changing-Over Foreign Currency Booking. Annals of Faculty of Economics, University of Oradea, Faculty of Economics, 1, 664-668. 